\title{
Self-Regulatory Dimension of Teachers' Intercultural Competence: Development and Psychometric Evaluation of New Scales
}

\section{Blagica Zlatković}

Faculty of Education in Vranje, University of Niš

\section{Danijela S. Petrović}

Department of Psychology, Faculty of Philosophy, University of Belgrade

\section{Milica Erić ${ }^{1}$}

Department of Psychology, Faculty of Philosophy, University of Belgrade

\section{Bruno Leutwyler}

University of Teacher Education Zug

\section{Tijana Jokić}

Centre for Education Policy, Belgrade

\begin{abstract}
Self-regulation is a key issue for teachers. Self-regulatory competencies help teachers maintain both their well-being and professional commitment. This is of particular importance when it comes to teaching in culturally diverse classrooms. However, this facet is generally neglected when Teacher Education supports pre- and inservice teachers in the development of their intercultural competencies. Against this background, the current paper deals with the development of three scales for the assessment of self-regulatory aspects of teachers' intercultural competence the Teacher Cultural Diversity Flexibility Scale (TCDFS), the Teacher Cultural Diversity Emotional Regulation Scale (TCDERS), and the Teacher Cultural Diversity Tolerance for Ambiguity Scale (TCDTAS). Each scale was developed and validated in two forms: one referring to minority students in general, and one referring specifically to Roma students. The results indicate generally good reliabilities (as from .74 to .91) and a unifactorial structure for each of the proposed scales. Both forms (general and the one for the Roma) of the TCDFS and the TCDERS also demonstrated concurrent validity. An assessment based on these scales may better inform training interventions aiming to develop self-regulatory aspect of teachers' intercultural competence and to measure the outcomes and efficacy of such
\end{abstract}

$1 \quad$ PhD student 
interventions. However, correlation analyses have also revealed some weaknesses of the TCDTAS. In the light of these results, further efforts should be directed at reanalysing the construct of self-regulation in dealing with diversity.

Key words: teachers' intercultural competence, self-regulation, flexibility, emotional regulation, ambiguity tolerance, assessment.

\section{Introduction}

Self-regulation in the school context. Self-regulation in the context of professional competence refers to how teachers manage their own resources in a professional setting (Klusmann, 2013). While research on students' selfregulation during the learning process is extensive (e.g., Bandura, 1993, 1997; Flammer, 1995; Zimmeman, 2001, 2002), studies on teachers' self-regulation in the school context are relatively scarce (Woolfolk Hoy \& Burke-Spero, 2005). Given the complexity of teachers' job and the number of tasks that they perform while teaching, self-regulation may be an important competence that helps maintain both well-being and professional commitment. In addition to the time spent in organizing learning activities, more and more time is required for performing tasks outside the classroom, such as planning and preparing classes, as well as administrative duties. The aforementioned aspects result in long working hours, increased workload and stress, and ultimately in reduced job satisfaction, which can indirectly also reduce student achievement (Klusmann \& Richter, 2014, in Mattern \& Bauer, 2014). Previous studies have shown that teachers with better self-regulation feel less emotional exhaustion, and accordingly can put more energy and resources into other professional challenges (Hobfoll, 2002). It is assumed that self-regulation is beneficial in dealing with the professional stress that teachers face during and after working hours, and increases job satisfaction (Mattern \& Bauer, 2014; Philipp \& Kunter, 2013). Teachers' self-regulation is usually observed through the reciprocal influence of two factors: engagement at work and elasticity. The basic assumption of this approach is that high engagement at work, combined with the aptitude to emotionally distance oneself from it, contributes to higher resilience and successful professional engagement (Klusmann, Kunter, Trautwein, Lüdtke \& Baumert, 2008). A typological approach thus differentiates between four types of self-regulation along the dimensions of engagement and resilience: $\mathrm{H}$ (healthy-ambitious), $\mathrm{U}$ (unambitious), A (excessively ambitious), and $\mathrm{R}$ (resigned), with $\mathrm{H}$ being the most and $\mathrm{R}$ being the least adaptive in terms of occupational stress (Schaarschmidt \& Ficher, 1996, in Mattern \& Bauer, 2014).

Self-regulation in Baumert and Kunter's (2013) theoretical model. The importance of self-regulation is also recognized in the theoretical model of teachers' professional competencies developed by Baumert and 
Kunter (2013). This model defines teachers' professional competence as an interplay of four main components, required to meet the manifold demands of this profession: (1) professional knowledge; (2) values, beliefs, and goals; (3) motivational orientation; and (4) self-regulation. Professional knowledge refers to both declarative and procedural knowledge in different domains, such as content knowledge, pedagogical content knowledge, psychological knowledge, organizational knowledge, etc. Values, beliefs, and goals relate to teachers' subjective theories about a specific educational topic, along with the subjective relevance of specific educational aims. Motivational orientations comprise control beliefs and intrinsic motivation. Self-regulation entails appropriate engagement, dealing with frustrations, as well as maintaining a healthy distance (Baumert \& Kunter, 2013).

The basic proposition of this model is that a teacher is competent only if his/her professional knowledge is related to productive values and beliefs, appropriate motivational orientations, and an adequate self-regulation. The model defines self-regulation as teachers' ability to invest personal resources in the professional context (Baumert \& Kunter, 2013). In other words, the teachers with the developed self-regulatory skills show a level of work-related engagement that is balanced with the challenges of the teaching profession. At the same time, they succeed in maintaining a healthy distance from work concerns and sustain their personal resources (Klusmann, 2013). Thus, selfregulation represents the adaptive use of the teacher's own resources. The central tasks of a teacher include modelling learning situations and activities, as well as supporting, encouraging and monitoring students during the process of active learning (Baumert \& Kunter, 2013). In performing these tasks, teachers are faced not only with the expectations of the students, but also those of parents, colleagues, school administrators, and the general public. In order to handle the complex situations encountered in their professional surroundings, teachers need to be flexible. For this reason, Baumert and Kunter (2013) see the ability to successfully manage one's personal resources as adaptive self-regulation, and consider it to be an important aspect of teachers' professional competence.

Self-regulation in a culturally diverse classroom. There is a specific meaning to self-regulation when it comes to teaching in a culturally diverse classroom. Although cultural diversity is not a new social phenomenon, acting in the context of diversity remains a source of concern, anxiety and stress for teachers at different stages of their professional development (e.g., Brouwers \& Tomic, 2000; Buchori \& Dobinson, 2012; Simic, 2014; Tatar \& Horenczyk, 2003). In many countries, a greater need is identified for the development of teachers' awareness and sensitivity to cultural differences, even in the course of initial professional education (e.g., Cochran-Smith, Davis \& Fries 2004; Hollins \& Guzman, 2005; OECD, 2010; OECD 2014; Pantić, Closs \& Ivošević, 
2011). The professional engagement of teachers in their work with students from minority groups, especially with Roma students, is further hampered by the lack of motivation to work with such students, prejudice against them, and insufficient knowledge about their culture (Kirilova \& Repaire, 2003). Previous research in Serbia has indicated that students of education, i.e., future teachers, are aware of the discrimination of Roma pupils in schools (Petrović, 2010). Yet, they are also not willing to make closer contact with Roma families, and they oppose the education of Roma pupils in mainstream schools (Peček, Macura-Milovanović \& Vujisić-Živković, 2014). Thus, when actually working with Roma students, teachers may find themselves in a position which bears considerable emotional pressure and difficulty in dealing with professional stress, which, in turn, can result in lowering educational standards and expectations for Roma children (Biro, Smederevac \& Tovilović, 2009). Improving the ability of teachers' self-regulation, on the other hand, could result in better quality of teaching activities, a higher level of job satisfaction, and lower levels of professional exhaustion during work with minority students.

Teachers' intercultural competence (ICC). The importance of preparing future teachers to work with cultural diversity in Serbia has been insufficiently recognized by the educational institutions responsible for initial teacher education (Petrović, 2016). Accordingly, recent research has found Serbian teachers to display poor intercultural sensitivity (Jokić \& Petrović, 2016; Petrović \& Zlatković, 2009) and a lack of knowledge, strategies, and tools needed for dealing with diversity in the classroom (Macura-Milovanović, Pantić, \& Closs, 2012; Vranješević, 2014; Zlatković \& Petrović, 2016).With this in mind, it seemed crucial to develop appropriate means to support both pre-service and in-service teachers. This concern was the starting base for the project reported in the present paper $^{2}$. The project's general aim was to develop an instrument which permits those who educate and train future teachers to shift their instruction on intercultural education from a normatively imbued top-down training (that is mostly ineffective) towards a needs-based approach (Leutwyler, Petrović, \& Mantel, 2012).

In order to develop such a tool, we saw it as necessary to merge two approaches which are rarely brought together: the tradition of 'interculturalists', with its rich and manifold literature on intercultural competencies (see, Deardorff, 2009; Perry and Southwell, 2011), and the conceptual approaches of teacher education, which focus on school-specific professional demands,

2 The 'Serbian Education for Roma Inclusion: Understanding and assessing teachers' intercultural sensitivity in Serbia' project was supported by SCOPES [Scientific CoOperation between Eastern Europe and Switzerland - grant number IZ73O_152481/1] and the Ministry of Education, Science and Technological Development, Republic of Serbia [project number 179018]. 
i.e., on teacher competencies. We found Baumert and Kunter's (2013) theoretical model of teachers' professional competencies to be the most suitable framework for linking the conceptual language of 'interculturalists' with that of teacher education. We started our research with an overview of relevant conceptualizations and operationalizations of the ICC, put forth by intercultural researchers (Bhawuk \& Brislin, 1992; Deardorff, 2006; Fantini, 2009; Kelley \& Meyers, 1995; Koester \& Olebe, 1988; Landis, Bennet, \& Bennet, 2004; Olson \& Kroeger, 2001; Munroe \& Pearson, 2006; Perry \& Southwell, 2011; Ruben, 1976; Ruben \& Kealey, 1979; Van der Zee \& Van Oudenhoven, 2000; Wang, Davidson, Yakushko, Savoy, Tan, \& Bleier, 2003), and with an identification of the specific dimensions and aspects of the ICC proposed in their contributions that are relevant from the standpoint of teacher competences. The identified dimensions included Beliefs, Values and goals dimension (Appreciation of Cultural Diversity, Attitudes toward Acculturation, Ethno-relative World View and Goals of Intercultural Education) (see Leutwyler, Petrović \& Jokić, shortcoming); Motivational dimension (Cultural diversity enthusiasm, Cultural diversity self-efficacy, Commitment to Social Justice) (see Petrović, Jokić \& Leutwyler, 2016) and Self-regulatory dimension (Emotional Regulation, Flexibility, Tolerance for Ambiguity). After that, we placed these dimensions within Baumert and Kunter's model of teachers' professional competencies and transferred them to a school-specific context. We thus arrived at a model of teaching-specific aspects of teachers' intercultural competence (Petrović, Zlatković, Jokić, Erić, Dimitrijević, \& Leutwyler, 2016). In the present paper, we elaborate on the self-regulatory aspects of teachers' intercultural competence, as established in our model.

Self-regulation as an aspect of teachers' ICC. We define self-regulation in dealing with cultural diversity as the teachers' ability to manage their own behavioural and emotional engagements in response to unexpected, demanding and stressful intercultural situations in the classroom and school setting. Our model distinguishes between three aspects of self-regulation in handling cultural diversity:

(1)Teachers' flexibility in dealing with cultural diversity. Teacher flexibility is seen as the ability to adjust one's behaviour to new and unfamiliar situations in the culturally diverse classroom. Teachers who are flexible are able to change their behavioural patterns in response to the unexpected or constrained circumstances within a culturally diverse classroom (e.g., they may instantly adapt their lesson if they notice that minority students cannot follow it, or they find ways to manage situations when minority students are not behaving as is expected from the viewpoint of the dominant culture). 
(2) Teachers' emotional self-regulation related to diversity. With regard to teachers' intercultural competence, we define emotional self-regulation as the ability to monitor and manage emotional reactions which arise in stressful intercultural situations. In other words, emotional selfregulation refers to the extent of teachers' awareness of their emotional reactions and the ways to cope with them in stressful intercultural situations in the school context. Teachers with high emotional self-regulation are expected to know how to relax when they find themselves overwhelmed by professional demands related to minority students, or how to calm down when they are irritated by a minority student's misbehaviour.

(3) Teachers' tolerance of ambiguity related to diversity. The third aspect of teachers' self-regulation refers the degree of teachers' emotional tolerance related to demanding and unpredictable school-specific intercultural situations. Teachers with high tolerance of ambiguity do not perceive demanding and unpredictable intercultural situations at school as emotionally threatening and provoking frustration, anxiety, and discomfort. On the other hand, teachers with low tolerance of ambiguity feel anxious and uncomfortable when they are uncertain about the meaning of a minority student's behaviour, or when they find themselves in ambiguous situations in the classroom with minority students.

\section{The Present Study}

Working from the above conception, we aimed at developing a threepartite instrument that would reliably assess each of the proposed three selfregulatory components of teachers' ICC. Two versions of the instrument were developed - one referring to minority students in general, and one referring specifically to the Roma population. Both versions were subjected to an extensive psychometric evaluation, testing their internal consistency, as well as their factorial and convergent-discriminant validity.

Research on teachers' beliefs about cultural differences shows that their intercultural sensitivity changes depending on the status that a particular minority group has in the society and the characteristics attributed to that minority group (see Dimitrijević, Petrović \& Leutwyler, 2017). With this in mind, we decided to develop two versions of the scales because, in Serbia, the Roma minority has the most unfavourable social status, accompanied with negative stereotyping. For example, the attitude towards the Roma is characterized by a high social distance (Frenčesko, Mihić \& Kajon, 2005; Miladinović, 2008), and teachers from Serbia justify the school failure of Roma students by the Roma lifestyle and family characteristics, parents' low investment in education and Roma students' lack of motivation for school work (Macura-Milovanović, Pantić \& Closs, 2012; Macura-Milovanović and Peček, 2013; Petrović, 2010). 


\section{Method}

\section{Participants}

A total of 204 students in education participated in the study. All participants were attending the Faculty of Teacher Education in either Vranje or Jagodina (Serbia). We only recruited the students who were enrolled in the second year of studies or higher to make sure that they had enough experience in the classroom to be able to provide valid answers to the questions used in the study. The sample was predominantly composed of female students $(87 \%$, in contrast to $13 \%$ of male students). The age of the participants ranged from 19 to 37 , with a mean of 21.6.The majority of participants grew up in a multiethnic community (44\%), had travelled abroad more than three times (38\%) and had cross-cultural friendships (56\%). Additionally, $76 \%$ participants considered themselves to have experience with cultural diversity.

\section{Measures}

The Self-Regulation Scales. Given the aim of this study, we use this section to detail the development of the main instrument, i.e., three scales for the assessment of self-regulatory aspects of teachers' ICC. The items for the Self-Regulation Scales were developed by adapting the instruments designed to assess the ICC to fit the considerations of teachers' education and competencies. A pool of selected items from the analysed instruments were adjusted so as to cover the content of the three components of self-regulation related to diversity, described in the Introduction. In the cases where the adjusted items were not sufficient to fully operationalize these components, we developed completely new items. All items were in the form of declarative statements for which varying degrees of agreement can be expressed, and were thus accompanied by a 4-point Likert-type scale to indicate the level of agreement. A total of eighty-six items were developed: the Teacher Cultural Diversity Flexibility Scale (TCDFS) and the Teacher Cultural Diversity Emotional Regulation Scale (TCDERS) each comprised a total of 22 items (11 general and 11 Roma-specific); the Teacher Cultural Diversity Ambiguity Tolerance Scale (TCDATS) was represented by 42 items ( 21 general and 21 Roma-specific).

Besides the new instruments, three other instruments were administered in order to test for convergent validity.

Cognitive Flexibility Scale (Martin \& Rubin, 1995). This twelve-item instrument is intended to measure person's cognitive flexibility (e.g., 'I have many possible ways of behaving in any given situation'; 'I am willing to work at creative solutions to problems'), which includes '(a) awareness that in any 
given situation there are options and alternatives available, (b) willingness to be flexible and adapt to the situation, and self-efficacy or belief that one has the ability to be flexible' (Martin \& Rubin, 1995, p. 623). The scale has an overall reliability coefficient of 0.83 (Martin \& Rubin, 1995) and has demonstrated concurrent, construct and criterion-related validity (Martin \& Rubin, 1995; Martin \& Anderson, 2009). The scale's internal consistency in this study was 0.72 . A significant positive correlation with this scale would support the validity of the newly developed scales as the measures of teachers' capabilities to easily change cognitive, emotional and behavioural patterns in order to adapt to the conditions within a culturally diverse classroom.

Cognitive Reappraisal Subscale (from the Emotion Regulation Questionnaire, Gross \& John, 2003). This six-item subscale is designed to measure emotion regulation strategies in the form of cognitive reappraisal (e.g., 'When I'm faced with a stressful situation, I make myself think about it in a way that helps me stay calm'). According to Gross and John (2003), the internal consistency indices for the Reappraisal subscale are satisfactory (ranging from .75 to .82 ). The scale's alpha in the present study was .79. This instrument has been chosen for validation since a significant positive correlation would confirm that the new scales measure how successful a teacher is in calming down, taking an optimistic attitude, and reinterpreting stressful situations arising from the diversity of the student body in the classroom.

The Multiple Stimulus Types Ambiguity Tolerance Scale-II (MSTATII) (McLain, 2009). This thirteen-item instrument (e.g., 'I avoid situations that are too complicated for me to easily understand'; 'I dislike ambiguous situations') measures ambiguity tolerance as an orientation, ranging from aversion to attraction, towards stimuli that are complex, novel, unfamiliar, and insoluble. Previous studies (see McLain, 2009) report satisfactory reliability of the scale (ranging from .79 to .83 ). Scale reliability in this study was 0.78 . A positive significant correlation of the three newly developed scales with this one would suggest that the new scales measure the constructs related to successful handling of complex, novel and unpredictable intercultural situations that occur in culturally diverse classroom and schools.

For all the above instruments, responses were given on a 4-point scale ranging from 1 (strongly disagree) to 4 (strongly agree).

\section{Procedure}

Participation in the study was completely voluntary. The newly developed scales and the measures chosen to establish their construct validity were administered to participants with their informed consent. The instruments were administered by researchers in the project, who described the general 
goal of the study and gave the necessary instructions to students. Additionally, students were encouraged to imagine that they taught a culturally diverse classroom, and to give their answers based on the anticipation of their own behaviour in such a situation.

Given that the aim of this study was to develop multiple measures with multiple items, a procedure for the psychometric correction and evaluation of the constructed instruments was established, based on the relevant literature about scale construction and revision (DeVellis, 1991; Raubenheimer, 2004; Reise, Waller, \& Comrey, 2000; Streiner, 2003). The process included a threestep analysis with the aim to select items for the final version of all subscales. The steps were: (1) Reliability analysis, (2) Exploratory factor analysis of single subscales, and (3) Exploratory factor analysis of all items.

\section{Results}

Reliability analysis. The first step in our analysis was to test the internal consistency of the proposed scales (Wille, 1996, in Raubenheimer, 2004). It served to point out the items that were lowering Cronbach's alpha values and items (Cronbach, 1951) with low item-total correlations $(<0.4)$. Based on this reliability analysis, four items were excluded (one from the TCDFS general, one from the TCDFS Roma-specific, one from the TCDTAS general, and one from the TCDTAS Roma-specific), which yielded an increase in scale reliabilities. Excluded items differed from others due to reverse coding. The TCDERS remained as it was after this step, both its general and Romaspecific version.

Exploratory factor analyses. The objective of the second step was to identify those items that most clearly represent the content domain of the underlying construct. We aimed to retain only those items that clearly loaded on a particular factor. Items belonging to each of the 6 constructed subscales were factorized in a separate analysis (extraction method: Principal Axis Factoring; Promax rotation). The criteria for retaining items were the following: (1) communality in the extraction column of 0.4 and above (Field, 2005), (2) an appropriate loading of .50 or larger, (3) in the case of one item loading on another factor, a loading twice as strong on the appropriate (first) factor than on any other (see Hinkin, Tracey \& Enz, 1997). This step ensured that all items that were not well represented in the common factor space and did not correspond sufficiently to the extracted factors were eliminated from the subscales, leaving only the items that measure the same construct. After this step, 7 items were excluded from the TCDFS (4 items from the general and 3 from the Roma-specific version), 
9 items were excluded from the TCDERS (6 items from the general and 3 from the Roma-specific version), whereas 22 items were excluded from the TCDATS (11 items from the general and 11 from the Roma subscale). Certain items were excluded from the TCDFS, including those that were too general (e.g. 'I'm not bothered with unforeseen situations in the class with minority students'; 'I think that I'm quite flexible when it comes to teaching Roma students), as well as those that were too concrete or specific (e.g. 'When I notice that a minority student does not understand my instruction, I easily find another way to explain the same assignment'; 'When school activities are not in accordance with needs of the Roma students, it's not a problem for me to come up with alternative activities for them'). The items excluded from the TCDERS referred to the easiness of dealing with negative emotions (e.g. 'If I find myself upset at minority/Roma students' behaviour, it's easy for me to calm down'), self-reflection in emotionally disturbed situations (e.g. 'When I see that minority/Roma student's behaviour has upset me, I reconsider my previous response to his/her behaviour') and persistence in teaching practice despite negative emotions (e.g. 'When I get upset with developing alternative assignments and activities for minority students, I do not let negative emotions affect the quality of this process; 'When ensuring inclusion of Roma students in the classroom gets strenuous, I try to prevent negative emotions from affecting my engagement'). The items excluded from the TCDATS mainly refer to lack of information regarding minority/Roma students (e.g. 'I function poorly when there is a lack of information about minority/Roma students'; 'I feel disturbed when I lack information about minority/Roma student's family') or imply a clearcut solution for dealing with minority/Roma students (e.g. 'I prefer to work in situations with minority/Roma students when a clearly defined approach leads to a solution'; 'I prefer situations with minority/Roma students if a clear 'best solution' is at hand').

Exploratory factor analyses of all items. In order to ensure that items from the three newly developed scales do load on three different factors, we performed an additional exploratory factor analysis with the total pool of items. The items that did not have primary loadings on the factors that they conceptually belonged to were eliminated, in specific, two items from the TCDTAS (one from the general and one from the Roma-specific version), and one item from the TCDERS (the Roma-specific version). After this step, we again conducted an EFA (PAF with Promax rotation) with the remaining items. This yielded a clearly interpretable three-factor structure (see Table 1 and Table 2). The extracted factors accounted for $49.85 \%$ of variance for the general and $54.14 \%$ of variance for the Romaspecific scales. 


\section{Table 1: Factor structure of Self-regulation Related to Diversity (general scales)}

\begin{tabular}{|c|c|c|c|}
\hline \multirow[b]{2}{*}{ Items } & \multicolumn{3}{|c|}{ Factor } \\
\hline & 1 & 2 & 3 \\
\hline \multicolumn{4}{|l|}{ Teacher Cultural Diversity Flexibility Scale (TCDFS) - General } \\
\hline $\begin{array}{l}\text { It's easy for me to manage situations when minority students don't follow my } \\
\text { lesson/teaching. }\end{array}$ & & .725 & \\
\hline $\begin{array}{l}\text { If I notice that minority students cannot follow, I easily find a way to adapt my } \\
\text { lesson/teaching on the spot. }\end{array}$ & & .718 & \\
\hline $\begin{array}{l}\text { It's easy for me to adapt my interventions in situations when minority students do } \\
\text { not behave as I expected. }\end{array}$ & & .644 & \\
\hline $\begin{array}{l}\text { I can easily deal with unexpected situations in the classroom with minority } \\
\text { students. }\end{array}$ & & .608 & \\
\hline $\begin{array}{l}\text { When I find myself in new situations with minority students, I know how to } \\
\text { appropriately adjust my behaviour. }\end{array}$ & & .530 & \\
\hline I think that I'm quite flexible when it comes to teaching minority students. & & .547 & \\
\hline \multicolumn{4}{|l|}{ Teacher Cultural Diversity Emotional Regulation Scale (TCDERS) - General } \\
\hline $\begin{array}{l}\text { When I find myself overwhelmed by professional demands related to minority } \\
\text { students, I know how to relax. }\end{array}$ & & & .645 \\
\hline $\begin{array}{l}\text { If I had a dispute with a minority student's parent, I would know how to calm } \\
\text { myself down. }\end{array}$ & & & .895 \\
\hline $\begin{array}{l}\text { I consider my actions very carefully, even in situations when I am irritated by a } \\
\text { minority student's misbehaviour. }\end{array}$ & & & .633 \\
\hline $\begin{array}{l}\text { When I find myself disappointed with my performance in a class with students } \\
\text { from minority cultures, I don't let negative emotions influence my future practice. }\end{array}$ & & & .484 \\
\hline $\begin{array}{l}\text { When the inclusion of minority students in the classroom becomes strenuous, I } \\
\text { try to prevent negative emotions from affecting my engagement. }\end{array}$ & & & .514 \\
\hline \multicolumn{4}{|l|}{ Teacher Cultural Diversity Ambiguity Tolerance Scale (TCDATS) - General } \\
\hline $\begin{array}{l}\text { I am anxious when I find myself in a situation with a minority student, which I } \\
\text { could not predict.* }\end{array}$ & .665 & & \\
\hline $\begin{array}{l}\text { I don't feel free to take action in situations when I am not certain how my } \\
\text { behaviour will affect students of minority groups.* }\end{array}$ & .572 & & \\
\hline $\begin{array}{l}\text { I feel frustrated when minority students answer my question in an ambiguous } \\
\text { way. }\end{array}$ & .789 & & \\
\hline $\begin{array}{l}\text { I'm uncomfortable with ambiguous situations in the classroom with minority } \\
\text { students.* }\end{array}$ & .806 & & \\
\hline $\begin{array}{l}\text { I'm bothered when minority students do their schoolwork according to some } \\
\text { other guidelines than what I expected.* }\end{array}$ & .761 & & \\
\hline $\begin{array}{l}\text { I feel uncomfortable with minority students when I don't really understand their } \\
\text { behavior. }\end{array}$ & 694 & & \\
\hline $\begin{array}{l}\text { The fact that it is not always clear what is right or wrong when dealing with } \\
\text { minority students makes me feel uncomfortable.* }\end{array}$ & .660 & & \\
\hline $\begin{array}{l}\text { If I am uncertain about the meaning of a minority student's behaviour, I get very } \\
\text { anxious.* }\end{array}$ & .597 & & \\
\hline
\end{tabular}

${ }^{\star}$ Reverse coded items

Note: All items were administered in Serbian and the table represents a translation of the original items. 
Table 2. Factor structure of Self-Regulation Related to Diversity (Roma scales)

\begin{tabular}{|c|c|c|c|}
\hline \multirow[b]{2}{*}{ Items } & \multicolumn{3}{|c|}{ Factor } \\
\hline & 1 & 2 & 3 \\
\hline \multicolumn{4}{|l|}{ Teacher Cultural Diversity Flexibility Scale (TCDFS) - Roma } \\
\hline $\begin{array}{l}\text { It's easy for me to change my approach if I see that Roma students are not } \\
\text { following my presentation. }\end{array}$ & & & .692 \\
\hline $\begin{array}{l}\text { It's easy for me to manage situations when Roma students don't follow my } \\
\text { lesson/teaching. }\end{array}$ & & & .850 \\
\hline $\begin{array}{l}\text { I'm not bothered by the possibility of facing unfamiliar situations in a class with } \\
\text { Roma students. }\end{array}$ & & & .773 \\
\hline $\begin{array}{l}\text { If I notice that Roma students cannot follow, I easily find a way to adapt my } \\
\text { lesson/teaching on the spot. }\end{array}$ & & & .695 \\
\hline $\begin{array}{l}\text { It's easy for me to adapt my interventions in situations when Roma students do } \\
\text { not behave as I expected. }\end{array}$ & & & .600 \\
\hline I can easily deal with unexpected situations in a classroom with Roma students. & & & .635 \\
\hline $\begin{array}{l}\text { When I find myself in new situations with Roma students, I know how to } \\
\text { appropriately adjust my behaviour. }\end{array}$ & & & .660 \\
\hline \multicolumn{4}{|l|}{ Teacher Cultural Diversity Emotional Regulation Scale (TCDERS) - Roma } \\
\hline $\begin{array}{l}\text { If I feel anxious about meeting with the parents of Roma students, I know how } \\
\text { to put myself at ease. }\end{array}$ & & .562 & \\
\hline $\begin{array}{l}\text { When a parent of a Roma student provokes me, I don't let negative emotions } \\
\text { get the best of me. }\end{array}$ & & .706 & \\
\hline $\begin{array}{l}\text { When I find myself overwhelmed by professional demands related to Roma } \\
\text { students, I know how to calm myself down. }\end{array}$ & & .845 & \\
\hline $\begin{array}{l}\text { If I had a dispute with a Roma student's parent, I would know how to calm } \\
\text { myself down. }\end{array}$ & & .788 & \\
\hline $\begin{array}{l}\text { I consider my actions very carefully, even in a situation when I am irritated by a } \\
\text { Roma student's misbehaviour. }\end{array}$ & & .741 & \\
\hline $\begin{array}{l}\text { When I find myself disappointed with my performance in a class with Roma } \\
\text { students, I don't let negative emotions influence my future practice. }\end{array}$ & & .661 & \\
\hline $\begin{array}{l}\text { When I realize that I haven't taught well in a class with Roma students, I try to } \\
\text { figure out what I can change next time. }\end{array}$ & & .646 & \\
\hline \multicolumn{4}{|l|}{ Teacher Cultural Diversity Ambiguity Tolerance Scale (TCDATS) - Roma } \\
\hline $\begin{array}{l}\text { I am anxious when I find myself in a situation with a Roma student, which I } \\
\text { could not predict.* }\end{array}$ & .661 & & \\
\hline I feel frustrated when Roma students answer my question in an ambiguous way.* & .772 & & \\
\hline $\begin{array}{l}\text { I'm uncomfortable with ambiguous situations which may arise in a classroom } \\
\text { with Roma students.* }\end{array}$ & .821 & & \\
\hline $\begin{array}{l}\text { I'm bothered if Roma students complete schoolwork according to some other } \\
\text { guidelines than what I expected.* }\end{array}$ & .752 & & \\
\hline $\begin{array}{l}\text { I feel uncomfortable with Roma students when I do not really understand their } \\
\text { behaviour.* }\end{array}$ & .792 & & \\
\hline $\begin{array}{l}\text { The fact that it is not always clear what would be right or wrong when dealing } \\
\text { with Roma students makes me feel uncomfortable.* }\end{array}$ & .824 & & \\
\hline $\begin{array}{l}\text { I tend to avoid situations with Roma students when the outcome is hard to } \\
\text { predict.* }^{*}\end{array}$ & .646 & & \\
\hline $\begin{array}{l}\text { If I am uncertain about the meaning of a Roma student's behaviour, I get very } \\
\text { anxious. }{ }^{*}\end{array}$ & .640 & & \\
\hline
\end{tabular}

${ }^{\star}$ Reverse coded items 
Internal Consistency after finalizing the scales. The aforementioned steps resulted in 6 scales, each exhibiting a unifactorial structure. Their alpha coefficients and number of items are given in Table 3.

Table 3. Cronbach's alpha and number

of items for the newly constructed scales

\begin{tabular}{lcc}
\hline & $\begin{array}{c}\text { General version } \\
\text { Alpha } \\
\text { (number of items) }\end{array}$ & $\begin{array}{c}\text { Roma version } \\
\text { Alpha } \\
\text { (number of items) }\end{array}$ \\
\hline Teacher Cultural Diversity Flexibility Scale & .744 & .882 \\
(TCDFS) & $(6)$ & $(7)$ \\
Teacher Cultural Diversity Emotional Regulation Scale & .841 & .881 \\
(TCDERS) & $(5)$ & $(7)$ \\
Teacher Cultural Diversity Ambiguity Tolerance Scale & .879 & .908 \\
(TCDTAS) & $(8)$ & $(8)$ \\
\hline
\end{tabular}

Correlation Analyses. Finally, Pearson correlations between the scores on all employed measures were calculated. Large correlations $(.70-.72)$ were found between the two forms (general and Roma) of the same scale. Moreover, TCDFS scores correlated strongly with TCDERS ( $r=.61$ for the general and $\mathrm{r}=.60$ for the Roma versions). However, the TCDATS (both versions) did not correlate significantly with two other newly developed scales. Table 4 shows correlations between the three new scales and the instruments used to establish their convergent validity. The TCDFS and TCDERS scores (both general and the Roma version) showed the expected pattern of correlations with two validation scales - the Cognitive Flexibility Scale and the Cognitive Reappraisal Scale, but a correlation with the third validation scale, the MSTAT-II, was not established (the only exception is a small correlation with the Roma version of the TCDERS). The TCDATS scores showed the expected pattern of correlations with two validation scales - the MSTAT-II and the Cognitive Flexibility Scale, but a negative correlation with the Cognitive Reappraisal Scale.

Table 4. Pearson correlation coefficients of the newly constructed scales scores with additional scales

\begin{tabular}{|c|c|c|c|c|c|c|}
\hline & \multicolumn{2}{|c|}{$\begin{array}{l}\text { Teacher Cultural } \\
\text { Diversity } \\
\text { Flexibility Scale } \\
\text { (TCDFS) } \\
\end{array}$} & \multicolumn{2}{|c|}{$\begin{array}{c}\text { Teacher Cultural } \\
\text { Diversity Emotional } \\
\text { Regulation Scale } \\
\text { (TCDERS) }\end{array}$} & \multicolumn{2}{|c|}{$\begin{array}{c}\text { Teacher Cultural } \\
\text { Diversity Ambiguity } \\
\text { Tolerance Scale } \\
\text { (TCDATS) }\end{array}$} \\
\hline & General & Roma & General & Roma & General & Roma \\
\hline $\begin{array}{l}\text { Cognitive Flexibility Scale } \\
\text { (Martin \& Rubin, 1995) }\end{array}$ & $.33^{* *}$ & $.25^{\star *}$ & $.41^{\star *}$ & $.38^{\star *}$ & $.33^{* *}$ & $.31^{\star *}$ \\
\hline $\begin{array}{l}\text { Cognitive Reappraisal Scale } \\
\text { (Gross \& John, 2003) }\end{array}$ & $.38^{\star *}$ & $.35^{\star *}$ & $.33^{* *}$ & $39^{* *}$ & $-.21^{\star *}$ & $-.23^{\star *}$ \\
\hline $\begin{array}{l}\text { The multiple stimulus types } \\
\text { ambiguity tolerance scale - } \\
\text { MSTAT-II (McLain, 2009) }\end{array}$ & .02 & .05 & .13 & $.16^{*}$ & $.60^{* *}$ & $.53^{* *}$ \\
\hline
\end{tabular}


Correlation analysis has suggested that the TCDATS (both general and the Roma version) could not be considered as an aspect of the intercultural competence as the TCDFS and TCDERS. Confirmatory factor analysis proves this result. We tested two models (general and the Roma) comprising of one latent construct (SR_G or SR_R) and five indicators. In order to make the model over-identified, we performed item parcelling (Brown, 2006; Kline, 2015) for two scales (TCDATS and TCDFS), and, hence, five indicators. The Maximum Likelihood with Satora-Bentler estimator was used as the estimation method. The results show acceptable fit of the models (SR_G: $\chi^{2}=4.73(3), \mathrm{p}<0.01$, RMSEA $=0.042$, CFI $=0.997$, TLI $=0.990$, SRMR=0.028; SR_R: $\chi 2=5.846(4), \mathrm{p}<0.01$, RMSEA=0.038, CFI $=0.997$, TLI $=$ 0.993 , SRMR $=0.028$ ) with the TCDFS and TCDERS as the only significant indicators of the latent construct, whereas the coefficient for the TCDATS was not statistically significant either in the general or in the Roma model.

\section{Discussion and conclusions}

The purpose of the study presented in this paper was to develop three scales which would reliably and validly assess the self-regulatory components of teachers' intercultural competence. The obtained results suggest that both forms (one referring to minority students in general, and one referring specifically to the Roma population) of the Teacher Cultural Diversity Flexibility Scale (TCDFS), Teacher Cultural Diversity Emotional Regulation Scale (TCDERS) and Teacher Cultural Diversity Ambiguity Tolerance Scale (TCDTAS) have good internal consistencies. In most cases, the newly developed scales had alphas above .80 (the only exception being the general version of the TCDFS with an alpha of .74). These results fit the requirements set by different statisticians (e.g., Cortina, 1993, Peterson, 1993 and Steiner, 2003, in Raubenheimer, 2004). Accordingly, this aspect of reliability of the newly developed scales may be considered as satisfactory, particularly given the small number of items comprising some of the scales.

Exploratory analyses have shown that same items have an extraction below .450 due to overly-general or overly-specific formulations (in case of the TDCEFS) and due to conceptual inconsistency (in case of the TCDTAS). However, after certain items had been excluded, exploratory factor analyses confirmed a unifactorial structure for each scale, thus supporting their structural validity.

Significant and moderate inter-correlations between the TCDFS and the TCDERS (both the general and the Roma form) indicate that these scales measure distinct, but related constructs. However, the TCDATS did not correlate with either the TCDFS or the TCDERS (the only exception was the small correlation between the TCDERS general form and the TCDATS Roma 
form). This result indicates that the TCDATS, as defined and developed within our model of teaching-specific aspects of teachers' intercultural competence, represents an aspect of ICC different and most likely unrelated to other selfregulatory facets of teachers' intercultural competence. This assumption is additionally supported by the results regarding the scales' convergent validity, which we discuss next.

Based on Westen and Rosenthal's (2003) propositions, the convergent validity of the new scales was assessed through correlations with the instruments that have been established as good measures of the same or overlapping constructs: cognitive flexibility, teacher emotional regulation, and ambiguity tolerance. Convergent validity for the TCDFS and TCDERS has been confirmed by significant correlations with the Cognitive Flexibility Scales (Martin \& Rubin, 2005) (.33 for the TCDFS general, .25 for the TCDFS Roma, .41 for the TCDERS general, and .38 for the TCDERS Roma) and the Cognitive Reappraisal Scale (Gross \& John, 2003) (.38 for the TCDFS general, .35 for the TCDFS Roma, .33 for the TCDERS general, and .39 for the TCDERS Roma. Given these results, we can conclude that both forms of the TCDFS and the TCDERS relate to previously established, more general measures in the area of cognitive flexibility and emotion regulation, i.e., such which do not specifically refer to the classroom setting (Gross \& John, 2003; Martin \& Rubin, 2005). The moderate correlations between the two newly developed scales for the assessment of self-regulation in a culturally diverse classroom, and previously constructed, well-established measures of selfregulatory processes in general, demonstrate that these instruments share a substantial amount of variance, but still measure different constructs.

However, neither version of the TCDFS correlated with the MSTAT-II (McLain, 2009), which is also true of the general version of the TCDERS. This finding suggests that these scales measure a construct that is distinct from tolerance for ambiguity. The TCDATS, however, has shown a substantial association with the MSTAT-II, implying that although it diverges from the self-regulatory aspects of teachers' intercultural competence; it does correspond to ambiguity tolerance as an attraction or aversion towards stimuli that are complex, unfamiliar, and insoluble.

In sum, the TCDFS and TCDERS correlated neither with the TCDTAS nor with the MSTAT-II, which was chosen as one of the external measures to validate the newly developed scales. On the other hand, the large correlation between the TCDTAS and the MSTAT-II scale implies that the TCDTAS has successfully captured the substance of ambiguity tolerance. Accordingly, we believe that the role of ambiguity tolerance as an aspect of teachers' self-regulatory competence is subject to further discussions. In the interculturalist literature, ambiguity tolerance - the ability to react to new and ambiguous situations with little visible discomfort - is argued to be an 
important dimension of intercultural competence and an important asset when adapting to a new and unfamiliar situations and environments (e.g., Ruben, 1976; Ruben \& Kealey, 1979). However, the results of this study imply that the ability to handle complex, novel, and unpredictable intercultural situations that occur in a culturally diverse classroom and school does not associate to cognitive and emotional aspects of self-regulation related to diversity. Another important consideration is that Baumert and Kunter (2013) define self-regulation as teachers' ability to invest personal resources in the professional context.

One weakness of this study is that the new scales were developed and validated on a sample of student-teachers. The participants in this research are in the initial stage of their preparation for the teaching profession, and therefore do not have enough knowledge and experience related to the professional context. It is possible that this problem is particularly evident in the case of ambiguity tolerance. We tried to diminish it by excluding firstyear students from the sample and by instructing the students to imagine that they taught a culturally diverse classroom and give their answers based on the anticipation of their own behaviour in such a situation. Nevertheless, it would be advisable to check the internal consistency and factor structure of all scales, as well as the assumption that the lack of professional knowledge and experience predominantly influences dealing with ambiguity in diverse classrooms, on a larger and more representative sample that includes studentteachers, novice teachers, and experienced teachers.

Taking into consideration the specific challenges that cultural, ethnic, and religious diversity places before teachers, it seems a pressing need to provide appropriate support for increasing the intercultural competence of pre-service and in-service teachers. In this respect, the development of instruments for assessing various aspects of intercultural competence in the school context seems to be of great importance (see Petrović, Jokić \& Leutwyler, 2016). Both forms of the Teacher Cultural Diversity Flexibility Scale (TCDFS) and Teacher Cultural Diversity Emotional Regulation Scale (TCDERS) that we developed to assess the self-regulatory aspects of teachers' intercultural competence, have demonstrated good reliability, factor structure, and adequate content and concurrent validity. In light of this, these scales could have various practical applications. For example, the results obtained by applying them may provide a basis for planning the training and pedagogical interventions aiming to develop self-regulation as a competence for dealing with diversity in the educational context. Furthermore, the scales could be used to measure the outcomes and efficacy of educational efforts, such as pre-service and inservice training programs.

Large correlations $(.70-.72)$ between the two forms (general and the Roma) of the same scale imply that these scales are equivalent in both versions. However, we believe that the Roma version of the scale grasps 
teachers' intercultural sensitivity more properly (see Dimitrijević, Petrović \& Leutwyler, 2017). Thus, we recommend the use of the Roma version of the scale in research dealing with the issues related to the inclusion of Roma children within the Serbian educational context.

Baumert and Kunter (2013) envisioned self-regulation as a distinct area of teacher competence. The present study builds on this postulation by attempting to demonstrate that self-regulation is also a core aspect of a teacherspecific intercultural competence, which helps teachers to maintain both their well-being and professional commitment. However, the identification of the components of self-regulation in dealing with diversity was not fully successful. Further research should be devoted to a reconceptualization of this construct, including an exploration of the extent to which variables such as growing up and residing in a multi-ethnic community, establishing contact or close relationships with persons from other cultures, knowledge about other cultures, attending courses related to intercultural education, teaching in a culturally diverse classroom, etc. are good predictors of the self-regulatory dimension of intercultural competence. Only on this basis, the approaches presented in this paper can be further developed in order to establish a wellgrounded and validated instrument. The development of such an instrument is of high importance, as it allows to move the self-regulatory dimension in the context of a comprehensive competence model, and to better inform training and pedagogical interventions for the development of a teachingspecific intercultural competence. The results of our approach have not yet fully proved the conceptual robustness of the presented model. Still, they show in no case that the self-regulatory dimension would not be an important part of a comprehensive teaching-specific intercultural competence. Therefore, further work on this neglected part is highly needed.

\section{References}

Bandura, A. (1993). Perceived self-efficacy in cognitive development and functioning, Educational Psychologist, 28, 117-148.

Bandura, A. (1997). Self-Efficacy: The experience of control. New York: Freeman.

Baumert, J., \& Kunter, M. (2013). The COACTIV model of teachers' professional competence. In M. Kunter, J. Baumert, W. Blum, U. Klusmann, S. Krauss, \& M. Neubrand (Eds.), Cognitive activation in the mathematics classroom and professional competence of teachers. Results from the COACTIV project (pp. 25-48). New York, NY: Springer.

Bhawuk, D. P., \& Brislin, R. (1992). The measurement of intercultural sensitivity using the concepts of individualism and collectivism. International Journal of Intercultural Relations, 16(4), 413-436.

Biro, M., Smederevac, S., \& Tovilović, S. (2009). Socioeconomic and cultural factors of low scholastic achievements of Roma children. Psihologija, 42(3), 273-288. 
Brouwers, A., \& Tomic, W. (2000). A longitudinal study of teacher burnout and perceived self-efficacy in classroom management. Teaching and Teacher education, 16(2), 239-253.

Brown, T. A. (2006). Confirmatory factor analysis for applied research. New York: Guilford publications.

Buchori, S., \& Dobinson. T. (2012). Cultural diversity in the early childhood classroom in Australia: Educators' perspectives and practices. The International Journal of Education for Diversities, 1, 41-56.

Cochran-Smith, M., Davis, D., \& Fries, K. (2004). Multicultural teacher education. In J. A. Banks \& C. A. Banks (Eds.), Handbook of research on multicultural education (pp. 931-975). San Francisco: Jossey-Bass.

Cronbach, L. (1951). Coefficient alpha and the internal structure of tests. Psychometrica, 16, 297-334.

Deardorff, D. K. (2006). Identification and Assessment of Intercultural Competence as a Student Outcome of Internationalization. Journal of Studies in International Education, 10, 241-266.

Deardorff, D. K. (2009). Synthesizing Conceptualizations of Intercultural Competence: A Summary and Emerging Themes. In D. K. Deardorff (Ed.), The SAGE Handbook of Intercultural Competence (pp. 265-270). Thousand Oaks: SAGE Publications.

DeVellis, R. F. (1991). Scale Development: Theory and Applications. Newbury Park, California: Sage Publications.

Dimitrijević, B., Petrović, D., \& Leutwyler, B. (2017). Implicitna uverenja nastavnika o učenicima romske i mađarske kulturne grupe [Teachers' Implicit Beliefs about the Students of the Roma and the Hungarian Cultural Group]. Zbornik Instituta za pedagoška istrazivanja, 49(1), 55-76. http://www.doiserbia.nb.rs/img/ doi/0579-6431/2017/0579-64311701055D.pdf

Fantini, A. E. (2009). Assessing intercultural competence. In D. K. Deardorff (Ed.), The SAGE Handbook of Intercultural Competence (pp. 456-476). Thousand Oaks: SAGE Publications.

Flammer, A. (1995). Developmental analysis of control beliefs. In A. Bandura, (Ed.), Self-efficacy in Changing Societies (pp. 69-113). New York: Cambridge University Press.

Franceško, M., Mihić, V., \& Kajon, J. (2005). Socijalna distanca i stereotipi o Romima kod dece novosadskih osnovnih škola [Social distance and stereotypes about Roma people in elementary school]. Psihologija, 39(2), 167-182.

Gross, J. J., \& John, O. P. (2003). Individual differences in two emotion regulation processes: Implications for affect, relationships, and well-being. Journal of Personality and Social Psychology, 85(2), 348-362. http://dx.doi.org/10.1037/00223514.85.2.348

Hinkin, T. R., Tracey, J. B., \& Enz, C. A. (1997). Scale construction: Developing reliable and valid measurement instruments, Cornell University. Retrieved June 2016 from http://scholarship.sha.cornell.edu/articles/613

Hobfoll, S. E. (2002). Social and psychological resources and adaptation. Review of General Psychology, 6, 307-324. 
Hollins, E. R., \& Guzman, M. T. (2005). Research on preparing teachers for diverse populations. In M. Cochran-Smith \& K. M. Zeichner (Eds.), Studying teacher education: The report of the AERA Panel on Research and Teacher Education (pp. 477-548). Mahwah, NJ: Lawrence Erlbaum.

Jokić, T. \& Petrović, D. (2016). Interkulturalna osetljivost nastavnika i činioci uspešnog sprovođenja interkulturalnog obrazovanja u Srbiji [Intercultural sensitivity of teachers and correlates of successful implementation of intercultural education in Serbia], In D. Petrović \& T. Jokić (Eds.) Interkulturalno obrazovanje u Srbiji - Regulativni okvir, stanje i mogućnosti za razvoj (pp. 128-154). Beograd: Centar za obrazovne politike.

Kelley, C., \& Meyers, J. (1995). CCAI: Cross-cultural adaptability inventory. Minneapolis, MN: National Computer Systems, Incorporated.

Kirilova, D., Repaire, V. (2003). The innovatory practices in the field of education of Roma children, Strasbourg: Council of Europe.

Kline, R. B. (2015). Principles and practice of structural equation modeling. New York: Guilford publications.

Klusmann, U. (2013). Occupational Self- Regulation. In M. Kunter, J. Baumert, W. Blum, U. Klusmann, S. Krauss \& M. Neubrand (Eds.), Cognitive activation in the mathematics classroom and professional competence of teachers. Results from the COACTIV project (pp. 291-308). New York, NY: Springer.

Klusmann, U., Kunter, M., Trautwein, U., Lüdtke, O., \& Baumert, J. (2008). Teachers' occupational well-being and quality of instruction: The important role of selfregulatory patterns. Journal of Educational Psychology, 100, 702-715.

Koester, J., \& Olebe, M. (1988). The behavioral assessment scale for intercultural communication effectiveness. International Journal of Intercultural Relations, 12(3), 233-246.

Landis, D., Bennet, J. M., \& Bennet. M. J. (Eds.) (2004). Handbook of Intercultural Training. Thousand Oaks, CA: Sage Publications, Inc.

Leutwyler, B., Petrović, D., \& Jokić, T. (2017/2018). The structure of teaching-specific intercultural competence: Empirical evidence on the aspects 'beliefs, values and goals'. Psihologija (accepted for publishing).

Leutwyler, B., Petrović, D., \& Mantel, C. (2012). Constructivist Foundations of Intercultural Education: Implication for Research and Teacher Training. In N. Popov, C. Wolhuter, B. Leutwyler, G. Hilton, J. Ogunleye \& P. Albergaria Almeida (Eds.), International Perspectives on Education (pp. 111-118). Sofia: Bulgarian Comparative Education Society.

Macura-Milovanović, S., Pantić, N., \& Closs, A. (2012). Challenges in developing teacher preparation for working inclusively in contexts of increasingly diverse populations-the case of Serbia. Prospects, 42, 19-39.

Macura-Milovanović, S., \& Peček, M. (2013). Attitudes of Serbian and Slovenian student teachers towards causes of learning underachievement amongst Roma pupils. International journal of inclusive education, 17(6), 629-645.

Martin, M. M., \& Anderson, M. C. (2009). The cognitive flexibility scale: Three validity studies. Communication Reports, 11(1), 1-9. 
Martin, M. M., \& Rubin, R. B. (1995). A new measure of cognitive flexibility. Psychological Reports, 76, 623-626.

Mattern, J., \& Bauer, J. (2014). Does teachers' cognitive self-regulation increase their occupational wellbeing? The structure and role of self-regulation in the teaching context. Teaching and Teacher Education, 43, 58-68.

McLain, D. (2009). Evidence of the properties of an ambiguity tolerance measure: The multiple stimulus types ambiguity tolerance scale-II (MSTAT-II). Psychological Reports, 105, 975-988.

Miladinović, S. (2008). Etnička i socijalna distanca prema Romima [Ethnical and social distance towards the Roma]. Sociološki pregled, 17(3), 417-437.

Munroe, A., \& Pearson, C. (2006). The Munroe Multicultural Attitude Scale Questionnaire: A New Instrument for Multicultural Studies. Educational and Psychological Measurement, 66(5), 819-834.

OECD (2010). Educating Teachers for Diversity: Meeting the Challenge. Paris: OECD Publishing.

OECD (2014). TALIS 2013 Results: An International Perspective on Teaching and Learning. Paris: OECD Publishing.

Olson, C., \& Kroeger, K. R. (2001). Global competency and intercultural sensitivity. Journal of studies in international education, 5(2), 116-137.

Pantić, N., Closs, A., \& Ivošević, V. (2011). Teachers for the future - teacher development for inclusive education in the Western Balkans. Torino: European Training Foundation.

Peček, M., Macura-Milovanović, S., \& N. Vujisić-Živković (2014). The cultural responsiveness of teacher candidates towards Roma pupils in Serbia and Slovenia - Case studies. Journal of Education for Teaching, 40(4), 359-376.

Perry, L. B., \& Southwell, L. (2011). Developing intercultural understanding and skills: models and approaches. Intercultural Education, 22(6), 453-466.

Petrović, D. (2010). To what extent do teachers perceive Roma discrimination in Serbian educational system, in M. Patricia (Ed.) Intercultural Education as Project for Social Transformation - Linking Theory and Practice towards Equity and Social Justice (pp. 156-172). Malta: Conference proceedings.

Petrović, D. (2016). Country Profile Serbia - Study on How Initial Teacher Education prepares student teachers to deal with Diversity in the Classroom. Vilnius: PPMI.

Petrović, D., Jokić, T., \& Leutwyler, B. (2016). Motivational Aspects of Teachers' Intercultural Competence: Development and Psychometric Evaluation of New Scales for the Assessment of Motivational Orientation. Psihologija, 49(4), 393-413.

Petrović, D., \& Zlatković, B. (2009). Intercultural Sensitivity of Future Primary School Teachers, In Popov, N. et al. (Eds.) Comparative Education, Teacher Training, Education Policy, Social Inclusion and Child Psychology (pp. 121-128). Sofia: Bulgarian Comparative Education Society.

Petrović, D., Zlatković, B., Jokić, T., Erić, M., Dimitrijević, B., \& Leutwyler, B. (2016). Competences for intercultural education: Conceptualization and Empirical Findings, In C. Pracana (Ed.) InPACT 2016 - International psychological applications conference and trends (pp. 355-359). Lisbon: Book of Proceeding. 
Philipp, A., \& Kunter, M. (2013). How do teachers spend their time? A study on teachers' strategies of selection, optimisation, and compensation over their career cycle. Teaching and Teacher Education, 35, 1-12.

Raubenheimer, J. (2004). An item selection procedure to maximise scale reliability and validity. SA Journal of Industrial Psychology, 30(4), 59-64.

Reise, S. P., Waller, N. G., \& Comrey, A. L. (2000). Factor analysis and scale revision. Psychological assessment, 12(3), 287-297.

Ruben, B. D. (1976). Assessing communication competency for intercultural adaptation. Group \& Organization Management, 1(3), 334-354.

Ruben, B. D., \& Kealey, D. J. (1979). Behavioral assessment of communication competency and the prediction of cross-cultural adaptation. International Journal of Intercultural Relations, 3(1), 15-47.

Simić, N. (2014). Nastavničke brige i načini njihovog prevazilaženja [Teacher concerns and coping mechanisms] (Neobjavljena doktorska disertacija). Filozofski fakultet, Univerzitet u Beogradu, Beograd.

Streiner D. L. (2003). Starting at the beginning: An introduction to coefficient alpha and internal consistency. Journal of Personality Assessment, 80(1), 99-103.

Tatar, M., \& Horenczyk, G. (2003). Diversity-related burnout among teachers. Teaching and teacher education, 19(4), 397-408.

Van Der Zee, K. I., \& Van Oudenhoven, J. P. (2000). The Multicultural Personality Questionnaire: A multidimensional instrument of multicultural effectiveness. European journal of personality, 14(4), 291-309.

Vranješević, J. (2014). The main challenges in teacher education for diversity. Zbornik Instituta za pedagoška istraživanja, 46(2), 473-485.

Wang, Y. W., Davidson, M. M., Yakushko, O. F., Savoy, H. B., Tan, J. A., \& Bleier, J. K. (2003). The scale of ethnocultural empathy: development, validation, and reliability. Journal of counselling psychology, 50(2), 221-234.

Westen, D., \& Rosenthal, R. (2003). Quantifying construct validity: two simple measures. Journal of personality and social psychology, 84(3), 608-618.

Woolfolk Hoy, A. and Burke-Spero, R. (2005). Changes in teacher efficacy during the early years of teaching: a comparison for four measures. Teaching and Teacher Education, 21, 343-356.

Zlatković, B. \& Petrović D. (2016). Interkulturalno obrazovanje budućih učitelja u Srbiji [Intercultural education of future class teachers in Serbia], In D., Petrović, \& T., Jokić (Eds.) Interkulturalno obrazovanje u Srbiji - Regulativni okvir, stanje $i$ mogućnosti za razvoj (pp. 76-87). Beograd: Centar za obrazovne politike.

Zimmerman, B. J. (2001). Theories of self-regulated learning and academic achievement: an overview and analysis. In B. J. Zimmerman, \& D. H. Schunk (Eds.), Self-regulated learning and academic achievement: theoretical perspectives (pp. 1-38). Mahwah, NJ: Erlbaum.

Zimmerman, B. J. (2002). Becoming a self-regulated learner: An overview. Theory into Practice, 41, 64-70. 


\title{
Samoregulatorna dimenzija interkulturalne kompetencije nastavnika: razvoj i psihometrijska validacija novih skala
}

\section{Blagica Zlatković}

Učiteljski fakultet $u$ Vranju, Univerzitet $u$ Nišu

\section{Danijela S. Petrović}

Odeljenje za psihologiju, Filozofski fakultet, Univerzitet u Beogradu

\section{Milica Erić}

Odeljenje za psihologiju, Filozofski fakultet, Univerzitet u Beogradu

\author{
Bruno Leutwyler \\ Univerzitet za obrazovanja nestavnika, Cug
}

\section{Tijana Jokić}

Centar za obrazovne politike, Beograd

\begin{abstract}
Samoregulacija je ključno pitanje za nastavnike. Samo-regulatorne kompetencije pomažu nastavnicima da sačuvaju kako osećanje lične sreće, zdravlja i uspeha, tako i posvećenost poslu. Ovo je od posebnog značaja kada je u pitanju nastava koja se realizuje u kulturno raznovrsnim odeljenjima. Međutim, edukatori budućih nastavnika i nastavnika najćešće zanemaruju ovaj aspekt u svojim nastojanjima da unaprede njihovu interkulturlanu kompetenciju. Umajući to u vidu, ovaj rad se bavi konstrukcijom tri skale za psihološku procenu samoregulatornih aspekata interkulturalne kompetencije nastavnika - Skala fleksibilnosti nastavnika za kulturnu raznolikost (TCDFS), Skala emocionalne regulacije nastavnika u susretu sa kulturnom raznolikošću (TCDERS) i Skala tolerancije neizvesnosti nastavnika na kulturnu raznolikost (TCDTAS). Svaka skala je razvijena i validirana u dve forme od kojih se jedna odnosi na učenike iz manjinskih grupa uopšte, a druga na romske učenike. Dobijeni rezultati ukazuju na dobru pouzdanost (alfa koeficijent od .74 do .91) i jednofaktorsku strukturu svih novokonstruisanih skala. Za obe forme (opšta i forma za romske učenike) Skale fleksibilnosti nastavnika za kulturnu raznolikost i Skale emocionalne regulacije nastavnika u susretu sa kulturnom raznolikošću utvrđena je zadovoljavajuća konkurentna validnost. Psihološke procene zasnivane na primeni ove dve skale, mogu da budu dobra osnova za diferencirano dizajniranje obuka i intevencije koje imaju za cilj da doprinesu razvoju samoregulatornog aspekta interkulturalne kompetencije nastavnika, a pored toga ove skale mogu da se koriste i za merenja ishoda i efikasnosti takvih intervencija. Međutim, koleralacione analize ukazuju na izvesne slabosti Skale tolerancije neizvesnosti nastavnika na kulturnu raznolikost. U svetlu tog rezultata, buduća nastojanja treba da budu usmerena na dodatno preispitivanje konstrukta samoregulacije i uloge koju samoregulacija ima u susretu sa kulturnim različitostima.
\end{abstract}

Ključne reči: interkulturalna kompetencija nastavnika, samoregulacija, fleksibilnost, emocionalna regulacija, tolerancija na neizvesnost, psihološka procena 